\title{
Syndrom pomocníka jako zdroj motivace pomáhajících profesí v hospicové péči Monika Vachová
}

\begin{abstract}
Abstrakt
U pomáhajících profesí je specifické, že nejčastějším motivem pro jejich volbu je vztah k pomoci. Osobnost pomáhajícího pracovníka se tím paradoxně stává rizikovým faktorem profesionální práce a potencionálním zdrojem problémů. Článek se zaměřuje na jednu z příčin motivace pomáhat, na tzv. syndrom pomocníka. Cílem je reflektovat práci osob se syndromem v hospicové péči, přičemž chceme poukázat na rizika spojená se vztahem pomocníka k umírajícím, pečujícím a pozůstalým, který ovlivňuje také fungování multidisciplinárního týmu a naplňování cílů hospicové péče.
\end{abstract}

Klíčová slova: paliativní péče, hospic, pomáhající profese, syndrom pomocníka, spasitelský syndrom

\section{Úvod}

Profesionalita a stabilita pracovního týmu jsou jedním ze základních předpokladů, aby docházelo k naplňování poslání a cílů organizace. V tomto kontextu je nepomíjitelným aspektem osobní rovina každého pracovníka a jeho motivace.

Z realizovaných průzkumů u pomáhajících profesí ${ }^{1}$ vidíme, že např. sociální pracovníci si vybrali své povolání, protože 1) chtěli pracovat s lidmi (37\%) nebo 2) jim chtěli přímo pomáhat (41 $\%)$. Téměř 4/5 respondentů uvedlo motivaci vycházející ze vztahu k druhým lidem. ${ }^{2}$ Zdravotní sestry a ošetřovatelé v nedávném rozsáhlém dotazníkovém šetření Ministerstva zdravotnictví České republiky odpověděli podobně $(68 \%) .{ }^{3}$ U pracovníků v hospicové péči se nadto specificky

1 Musil poukazuje na chybějící definici pojmu pomáhající profese, která současně vzniká popisem jednotlivých slov a jejich sloučením. Pojem následně definuje jako „... organizovanou skupinu pracovníků, kteří lidem v nesnázích poskytují specializovaný typ podpory nebo zdrojů s cílem umožnit jim zvládat jejich problémy či uspokojovat potřeby." Libor MUSIL, Sociální práce a jiné pomáhající obory/ profese, in: Encyklopedie sociální práce, ed. Oldřich MATOUŠEK, Praha: Portál, 2013, s. 506.

2 Srov. Markéta ELICHOVÁ a kol, Projekt specifického výzkumu Grantové agentury Jihočeské univerzityč. 117/2013/H: Pojetí kvality sociální práce $v$ souvislosti se sebedefinováním sociálního pracovníka a jeho profese, České Budějovice: Teologická fakulta Jihočeské univerzity, 2013. Pozn.: Výzkumného šetření se zúčastnilo 678 respondentů.

3 Výzkumu se zúčastnilo 15432 nelékařských zdravotnických pracovníků. Srov. @ MZČR, Největší motivací k práci je pro nelékaře možnost pomáhat druhým lidem, ukázalo dotazníkové šetření MZ (on-line), dostupné na: http://www.mzcr.cz/dokumenty/nejvetsi-motivaci-kpraci-je-pro-nelekare-moznost-pomahat-druhym-lidemukazalo-_16575_3970_1.html, publikováno dne 2. 1. 2019, citováno dne 27. 1. 2020. S podobnými výsledky byly realizovány výzkumy Heplové, Michálkové a Zacharové. Srov. Monika HEPLOVÁ - Helena MICHÁLKOVÁ, Motivační prvky v práci sestry, Sestra 11/2010, s. 30-31. Srov. Eva ZACHAROVÁ, Motivační faktory v sesterském povolání, Sestra 6/2010, s. 30. 
objevuje motivace k volbě práce s umírajícími založená na předchozí osobní zkušenosti se smrtí (nejčastěji se jedná o blízkou osobu). ${ }^{4}$ Také účastníci kurzů vztahujících se k procesům umírání či poradenství truchlícím jsou převážně motivováni k sebevzdělávání v této oblasti skrze zkušenost s osobním doprovázením blízké osoby pre finem, in finem, post finem. ${ }^{5}$ Motivy jedince jako psychologické př́íciny chování se však mohou projevovat nevědomě. ${ }^{6}$

Osobnost pracovníka ovlivňuje jeho pohled na klienta, rámec jeho pracovních postupů, využívání metod, strategií, jeho hodnocení, zda práce s klientem byla nebo nebyla úspěšná apod. ${ }^{7}$ Osobnost pomáhajícího pracovníka z těchto důvodů můžeme označit za rizikový faktor profesionální práce a potencionální zdroj problémů, který může být spojen se zneužíváním moci vyplývající


a identita profesí.

Zejména v sociální práci je tak stále více zdůrazňována reflexivní praxe jako schopnost kritického porozumění vlastnímu vlivu při práci s klientem s cílem kultivace sebe samého a zkvalitnění práce. ${ }^{9}$ Navrátil vnímá užitečnost reflexivity v přezkoumávání pracovníkových předpokladů a dalších skutečností, s nimiž pracovník vstupuje do vztahu s klientem, a upozorňuje, že „... pomáhající profesionál je (také člověk), který sice mentálně může chtít akceptovat rozmanitá metodická, manažerská či etická pravidla, ale přesto se mu to nemusí dařit." ${ }^{10}$

Osobnost pracovníka, jeho motivace i schopnost sebereflexe jsou součástí tématu této studie, ve které se zaměříme na jednu z rizikových motivací pomáhajících profesí, na tzv. syndrom pomocníka (dále také bezmocný pomocník / patologický altruista), ${ }^{11}$ a to specificky v oblasti hospicové péče. Samotný pojem nemá dosud jednoznačnou definici. ${ }^{12}$ První a dosud nejvýznamnější vhled do problematiky syndromu popsal německý psychoanalytik W. Schmidbauer již v roce 1977 v knize Die hilflosen Helfer: Über die seelische Problematik der helfenden Berufe. ${ }^{13}$ Pro syndrom

4 Srov. Šimon JELÍNEK, Setkání s umíráním a smrtí v hospici v kontextu sociální práce, Pražská vysoká škola psychosociálních studií, 2008, s. 40. Srov. Tereza PUDIVÍTROVÁ, Motivace pracovníků pomáhajících profesí k práci v Hospici sv. Jana N. Neumanna v Prachaticích. České Budějovice, 2020, s. 26-27. Bakalářská práce. Jihočeská univerzita v Českých Budějovicích. Teologická fakulta. Katedra etiky, psychologie a charitativní práce. Vedoucí práce Mgr. Monika Vachová. Pozn.: Výzkumy v oblasti profesní motivace zaměstnanců hospiců se objevují ve formě absolventských prací studentů zdravotních a sociálních oborů. Odborný diskurz reflektující motivace pracovníků pro výběr práce v zařízeních hospicového typu v současnosti chybí.

5 Toto tvrzení vyplývá $\mathrm{z}$ účasti autora článku na těchto kurzech či z jejich lektorování.

6 Profesní motivace a její teorie tvoří samostatné téma, které je u nás podrobně zpracováno psychologem a vysokoškolským pedagogem M. Nakonečným. Srov. Milan NAKONEČNÝ, Motivace pracovního jednání a její rízení, Praha: Management Press, 1992; Milan NAKONEČNÝ, Motivace chování, Praha: Triton, 2014, s. 171.

7 Srov. Frederic C. REAMER, Social work values and ethics, New York: Columbia University Press, 1999, s. 11. Pozn.: Výsledky výzkumů poukazují také na rozdíly při řešení situací s důrazem na komunikaci na emocionální rovině u žen s výraznější schopností empatie a kreativity při řešení situací a na mužskou zaměřenost na věcný objektivní náhled, větší rozhodnost a menší schopnost komplexního vnímání problému. Srov. Markéta ELICHOVÁ, Sociální práce: Aktuální otázky, Praha: Grada, 2017, s. 128-130. Srov. Radka JANEBOVÁ - Lucie ČERNÁ, Konstrukce žen-klientek a mužů-klientů v praxi sociální práce, Gender, rovné př́ležitosti, výzkum 2/2008, s. 37-45.

8 Kompetencemi pomáhajících profesí se u nás zabývá především Havrdová, která vytvořila často používanou modelovou soustavu kompetencí včetně upřesňujících kritérií. Srov. Zuzana HAVRDOVÁ a kol., Kompetence v praxi sociální práce: metodická př́ručka pro učitele a supervizory v sociální práci, Praha: Osmium, 1999, s. 41-42. Stanovení a aktualizace kompetencí pomáhajících profesí je úkolem jednotlivých asociací. Pro bližší studium lze doporučit komparaci kompetencí definovaných Americkou asociací vysokých škol ošetřovatelství a Radou pro vzdělávání v sociální práci. Srov. Joann DAMRON-RODRIGUES, Developing competence for nurses and social workers, The Journal of Social Work Education 3/2008, s. 27-37.

9 Mezi významné iniciátory reflexivní praxe patří např. D. Schön, zabývající se strategiemi reflexe především během procesu práce s klientem. Srov. Donald SCHÖN, The reflective Practitioner, London: Temple Smith, 1983.

10 Pavel NAVRÁTIL, Reflexivita v posouzení a v sociální práci, in: Reflexivita v posuzování životní situace klientek a klientů sociální práce, ed. Pavel NAVRÁTIL - Radka JANEBOVÁ a kol., Hradec Králové: Gaudeamus, 2010, s. 24.

11 Pozn.: Pojem syndrom pomocníka, tj. helper syndrome / Helfersyndrom, se objevuje v různých synonymech. Zmiňme např. mesiášský komplex, spasitelský syndrom, samaritánský syndrom či pachatelé dobra, patologická charita. Schmidbauer používá v tomto kontextu pojem bezmocný pomocník.

12 Pozn.: Pojmem „syndrom“ obecně definujeme jako soubor několika typických znaků vytvářejících určitý obraz a „pomocníkem“ rozumíme všechny pomáhající profese.

13 Wolfgang Schmidbauer poukázal na tento syndrom již v roce 1977. Srov. Wolfgang SCHMIDBAUER, Die hilflosen Helfer: Über 
pomocníka je charakteristická patologická snaha pomáhat, nevycházející z mravního principu nezištné služby bližnímu (altruismu), nýbrž z potřeby uzdravení vlastní duše. ${ }^{14}$ Syndrom pomocníka se může skrývat za projevy solidarity, altruismu, empatie aj. Bezmocný pomocník je obecně charakterizován jednáním v nevědomé sebeobraně, potlačuje osobní prožitky, emoce, vyhýbá se sebereflexi. Jeho potřeba pomáhat a zachraňovat druhé vede až k sebeponižování a sebepoškozování, zanedbávání sociálních vztahů. Výsledkem je často rozvoj úzkosti, deprese, syndromu vyhoření i mnohých zdravotních komplikací. ${ }^{15}$

Na syndrom pomocníka by mohlo být nahliženo z hlediska mnohých psychologických teorií, pohledem sociologie, teologie, biologie, evoluce aj. V současnosti jsou diskutovány dva pohledy, o které se zasloužili především Schmidbauer a Oakley.

(1) Schmidbauerovo pojetí je specificky orientované na příciny rozvoje syndromu pomocníka, které spatřruje $\mathrm{v}$ traumatech a nenaplněných potřebách $\mathrm{z}$ dětství ${ }^{16}{ }^{1} \mathrm{C}$ lem jeho psychoanalytického př́stupu je postupné „uzdravení, založené na zvědomění prožitků z dětství a pochopení jejich dopadu na současné chování. Doležel tuto koncepci dává do souvislosti s pojetím hlubinné psychologie, podle které se volba budoucího povolání utváří v prvních pěti letech života dítěte, ale vedle toho je již zdůrazněn vliv pozdějšího psychického vývoje včetně ovlivňujících duševních zranění. „V tomto období (tj. dětství - pozn. autora) přejímáme a zvnitřňujeme ideály našich rodičů, které považujeme často po celý život za závazek, a jejichž porušení nám způsobuje pocity viny. Právě tyto ideály hrají důležitou roli ve volbě pozdější profese. Mimo tyto okolnosti hrají roli při volbě pomáhající profese (...) i vlastní duševní zranění utrpěná během psychického vývoje. Podle pojetí hlubinné psychologie žijí traumata dále jako vytěsněné pocity ukřivděnosti, hněvu, strachu, méněcennosti nebo jako nenaplněná a nepřiznaná přání. Dokud tedy ona traumata dětství a pozdějš́ího vývoje neprojdou znovu vědomím, není naděje na skutečné uzdravení pomocníka ani jeho klientů. “17

Američtí psychologové Holmes a Rahe vytvořili škálu životních událostí jako významných stresorů, které mohou při jejich určitém součtu být významným narušitelem duševní rovnováhy. Nejvyšším počtem bodů (100) označili úmrtí partnera/partnerky ${ }^{18}$ Smrt představuje náročnou životní situaci, která souvisí se změnou vlastní identity, ztráty integrity, pocitem vlastního ohrožení charakterizované strachem, úzkostí aj. Proto se i v současné době s důrazem na individuálnost procesu ustupuje od konceptu rozlišování mezi „normálním“/nekomplikovaným a komplikovaným/patologickým truchlením. Přesto zůstávají v povědomí aspekty, které mohou zpracování smrti blízké osoby komplikovat. ${ }^{19}$ Přes individuálnost procesu truchlení Špaténková upozorňuje,

die seelische Problematik der helfenden Berufe, Hamburg: Rohwolt Verlag, 1977. Jeho známější kniha, vydaná v roce 2007, Syndrom pomocníka (Srov. Wolfgang SCHMIDBAUER, Syndrom pomocníka: podněty pro duševní hygienu v pomáhajících profesích, Praha: Portál, 2015.) obsahuje starší i nové vědecké poznatky původního vydání, které u nás vyšlo až v roce 2000 pod názvem Psychická úskalí pomáhajících profesí. Srov. Wolfgang SCHMIDBAUER, Psychická úskalí pomáhajících profesí, Praha: Portál, 2000.

14 SCHMIDBAUER, Syndrom..., s. 16.

15 Oakley upozorňuje, že patologický aktivismus se často objevuje spolu s poruchami jako je posttraumatická stresová porucha nebo obsedantně kompulzivní porucha. Srov. Barbara OAKLEY - Ariel KNAFO - Guruprasad MADHAVAN - David Sloan WILSON, Pathological Altruism, Oxford University Press, USA, 2012, s. 10-13.

16 Srov. SCHMIDBAUER, Syndrom..., s. 31-32.

17 Srov. Jakub DOLEŽEL, Osobnostní rizika pomáhající praxe: Syndrom pomocníka ve světle biblické moudrosti, Spravedlnost a služba III., in: Sborník odborných přispěvků a studijních textů CARITAS-VOŠ sociální Olomouc, ed. CARITAS-VOŠ sociální Olomouc, 2008 , s. 35.

18 Srov. Thomas HOLMES - Richard RAHE, The Social Readjustment Rating Scale, Journal of Psychosomatic Research 2/1967, s. 213218. Pozn.: Po kritice reagující na její nedostatky (např. druhy úmrtí - stárím či úmrtí mladého rodiče apod.) vznikla modernější De Meusova škála, kde je však hodnocení úmrtí blízkého člena rodiny také na nejvyšších pozicích stresorů. Srov. Libor MíčEK - Vladimír ZEMAN, Učitel a stres, Brno: Masarykova univerzita, 1992, s. 57-61.

19 Pozn.: Toto dělení používají např. Ulrichová a Špaténková (Kubíčková). Srov. Monika ULRICHOVÁ, Hledání smyslu ve smrti a utrpení: Zdravotně sociální aspekty konce života v perspektivě existenciální analýzy, Ostrava: Moravapress, 2014, s. 116-123. Srov. Naděžda KUBÍČKOVÁ, Zármutek a pomoc pozůstalým, Praha: Institut sociálních vztahů, 2001. 
že je nežádoucí, aby poradce pro pozůstalé (mj. každý hospicový pracovník) sám nebyl plně vyrovnán se smrtí blízké osoby. $V$ opačném případě je pravděpodobná neschopnost reflektivně posoudit, zda jedná profesionálně. Rizikem je např. zpracování vyrovnání se se smrtí neefektivními strategiemi pomocí ego-obranných mechanismů. ${ }^{20}$ Pracovník ovlivněn ztrátou může v této souvislosti využít sublimace a projektivní identifikace. Oba tyto nevědomé obranné postoje ve svém důsledku spojují osobní prožitek ztráty blízkého člověka s následnou dobročinností. Výzkumy ukazují, ${ }^{21}$ že vlastní prožitek procesu smrti blízké osoby či přímo její doprovázení je častou motivací pro práci v hospicové péči.

(2) Zatímco ve výše uvedeném je hlavní pozornost věnována bezmocnému pomocníkovi, Oakley se zabývá problémem patologického altruisty v souvislosti s důsledky jeho jednání na cílovou osobu či skupinu osob, které má být pomoženo, a zároveň na dopady jednání v širším sociálním prostředí, tj. na rodinu, pracovní kolektiv, jiné sociální vazby bezmocného pomocníka, na celou společnost. ${ }^{22}$ Vznik syndromu tzv. patologického altruismu odvíjí z evolučně prospěšného manického chování. ${ }^{23}$ Její pojetí je blízké systemickému přístupu v sociální práci. Každá příčina/jednání má svůj důsledek, přičemž se předpokládá, že změna interakčních pravidel vyléčí problémovou příčinu. Terapie patologického aktivisty nespočívá v psychoanalytické retrospekci bezmocného pomocníka, ale v hledání alternativ změny jeho jednání či komunikačních vzorců, které vedou k řešení důsledků / vzniklých problémů. Tj. neptáme se na otázku „proč“, ale především „jak“ (jaké řešení zapřičiní změnu jednání patologického aktivisty).

V následující části textu chceme poukázat na motivace bezmocného pracovníka k volbě pomáhající profese, konkrétně v hospicové péči. ${ }^{24}$ Nemůžeme ani zde nechceme objektivně posoudit, zda syndrom pomocníka u pracovníků v hospicové péči vznikl po neúplném zpracování úmrtí blízké osoby, nebo se u pracovníka projevil již dřive a setkání se smrtí jej pouze motivovalo pro výběr práce $s$ umírajícími v hospicové péči. ${ }^{25}$ Specificky se budeme věnovat konkrétním potenciálním projevům syndromu u pracovníků $\mathrm{v}$ hospici, které do značné míry ohrožují nejen umírajícího a jeho rodinu, ale celý multidisciplinární tým a cíle hospicové péče. Každá kapitola je uvedena instrumentální případovou studií sepsanou formou kazuistiky. Jedná se o modelové příklady, které jsou vzhledem k etické stránce problematiky finálně smyšlené. Byly sepsány strategií kombinace několika anonymizovaných skutečných kazuistik z praxe hospicové péče v České republice. ${ }^{26} \mathrm{Je}-$ jich účelem je především poukázat na symptomy obvyklé u patologických altruistů pracujících v hospicové péči, porozumět důležitým aspektům jejich jednání a ilustrativně poukázat na dopady jejich jednání ve třech vztahových oblastech: (1) na umírající a jejich pečovatele, (2) na pozůstalé a (3) na pracovní tým. Vzhledem k ojedinělosti tohoto tématu syndromu pomocníka v hospicové péči ${ }^{27}$ mohou tyto př́klady poskytnout zároveň prostor pro reflexi/sebereflexi.

20 Srov. Naděžda ŠPATÉNKOVÁ, Poradenství pro pozůstalé, Praha: Grada Publishing, 2013, s. 23.

21 Pozn. Viz výzkumy uvedené v úvodu a př́klady z praxe v následujících kapitolách.

22 Srov. OAKLEY, Pathological Altruism..., s. 3-9.

23 Srov. Barbara OAKLEY, Concepts and implications of altruism bias and pathological altruism, PNAS 2/2013, s. 408-415.

24 Pozn.: Mezi pomáhající profese hospicové péče řadíme zdravotní sestry, sociální pracovníky, lékaře, psychology, duchovní a další pracovníky v př́mé péči (např. pracovníky v sociálních službách, ošetřovatele, fyzioterapeuty aj.). Srov. Lukas RADBRUCH - Sheila PAYNE a kol., Standardy a normy hospicové paliativní péče v Evropě, Praha: Cesta domů a Česká společnost paliativní medicíny, 2010, s. $45-46$.

25 Pozn.: Př́iklady uvedené v jednotlivých kapitolách proto také nezohledňují rané dětství.

26 Tyto kazuistiky byly sesbírány metodou zúčastněného pozorování a nestandardizovanými rozhovory během setkání ředitelů mobilních hospiců v listopadu 2018. Na základě jejich analýzy byla interpretována data. Modelové př́klady v tomto článku pouze ilustrují způsoby jednání těchto pracovníků, jejich vnitřní motivy a postoje, vnější motivy (okolnosti, které je motivovaly k výběru profese aj.).

27 Pozn.: Téma syndromu pomocníka v hospicové péči není dosud dostatečně rozpracováno v odborné literatuře české ani zahraniční. 


\section{Syndrom pomocníka v péči o umírající a jejich blízké}

Příklad č. 1: Paní Alena pracuje jako zdravotní sestra v domácí hospicové péči. Vždy je k umírajícím a k jejich pečujícím (tj. nejčastěji rodině) velice milá, empatická, kreativní, obětavá. Snaží se jim vyjadřvat plnou podporu. Aktivně vyhledává různé způsoby pomoci. Pro rodiny v hmotné nouzi organizuje charitativní pomoc. Umírajícím zprostředkovává různé terapeutické činnosti. U mnohých rodin nedělá jen to, co se od ní očekává, ale dokáže pro ně udělat „první poslední, neumí ríkat „ne“. Ke „svým umírajícím“ dojiždí nad rámec pracovních povinností. Porušila v tomto kontextu několikrát vnitřní pravidla organizace práce. Např. dala pečujícím své soukromé telefonní ćíslo, aby mohli kontaktovat výhradně ji „ve dne v noci“. S mnohými rodinami se snaží udržovat soukromý kontakt také po ukončení hospicové péče, a to i nad rámec hospicem koordinované péče o pozůstalé. Snaží se udělat si z klientù své nejbližši prátele.

Vnitřně neustále bojuje o uznání a př́zeň, o pochvalu. Ráda dojíżí pouze tam, kde její náklonnost opětují, vyjadrujuí jí pozitivní zpètnou vazbu. Tyto rodiny by si chtěla nechat výlučnè ve své péči. Zde se cítí nezastupitelná. Využivá hodně fyzického kontaktu, často bez sebereflexe, zda ho umírající či pečující v takové míre chtějí. Proto v některých rodinách kvưli tomu dochází ke střetu. Má také problémy soslovováním klientů. Ve snaze o navázání blízkého vztahu, i přes odlišnost organizačních pravidel, nabizí častěji tykání. Použivá oslovení „babičko“, „dědečku“.

Práce v hospici je pro ni „srdcová záležitost“ a obětovala jí celý současný život, ve kterém sebe zanedbává. Vlastní rodinu doslovně „odsunula na druhou kolej“. Rodina to „musí pochopit“, podř́dit se její profesi a velkým nárokưm, které jsou s ní spojeny. Vždyt’ prece dělá záslužnou činnost. Ve volném čase navštěvuje rodiny, o které dřive pečovala, organizuje benefiční akce. Př́ćčnou a zároveň motivací k práci v hospici byla tragická smrt její sestry. O této události však nikdy nemluví.

Při poskytování paliativní péče je cílem kvalita života pacienta v souladu s jeho vysloveným přáním a postoji, tzv. dříve vysloveným práním. ${ }^{28}$ Platí zde základní pravidlo autonomie „volenti aegroti suprema lex“29. Opomineme-li právní aspekt vztahu mezi pracovníkem hospice a klienty, ${ }^{30}$ vzájemným etickým aspektem tohoto vztahu se obecně zabývají etické kodexy pomáhajících profesí a kodexy či standardy hospicových sdružení i jednotlivých organizací. ${ }^{31}$ Definují vztah založený především na 1) lidské důstojnosti a 2) orientaci na kvalitu života. ${ }^{32}$ Uskutečňování obou hodnot může být u bezmocného pracovníka komplikované.

Doležel, vycházející z Hermanna Stengera, rozvíjí tř̌i rizikové motivy pomoci u pracovníků

28 Srov. Zákon č. 372/2011 Sb., o zdravotních službách, \$36.

29 Tj. Vůle pacienta je nejvyšším zákonem. Srov. Jolana TĚŠINOVÁ a kol., Medicínské právo, Praha: C. H. Beck, 2011, s. 36-49. Prokop a Kabelka uvádějí, že „u autonomie subjektu nastává dilematická situace v př́padě, že pacient má sníženou schopnost racionálního uvažování při změně kvality vědomí. Nic to ale nemění na jeho subjektivním vnímání v úrovni př́jemných (bezpečných) či nepř́jemných (stresujících) pocitů. (...) Autonomie jedince se může projevovat na různých úrovních - aktuální přání, ale i životní preference, které jsou známé dopředu." Jiří PROKOP - Ladislav KABELKA, Etika paliativní péče, in: Paliativní medicína pro praxi, ed. Ondřej SLÁMA a kol., Praha: Galén, 2007, s. 319.

30 Hospicová péče v ČR je zákonem řešena pouze okrajově. Srov. Zákon č. 372/2011 Sb., o zdravotních službách, \$ 44a.

31 V České republice současně existují tři asociace sdružující instituce paliativní medicíny a členské hospice. Všechny disponují vlastním etickým kodexem či standardy: Asociace poskytovatelů hospicové paliativní péče, Česká společnost paliativní medicíny České lékařské společnosti Jana Evangelisty Purkyně a Fórum mobilních hospiců. Na mezinárodní úrovni jmenujme Evropskou asociaci pro paliativní péči.

32 Nejaktuálnější znění standardů, na kterém spolupracovaly všechny asociace v ČR, byt je konsensuálně přijaly nakonec dvě asociace ze třech (Fórum mobilních hospiců a Česká společnost paliativní medicíny), vedle těchto dvou principů klade důraz na individualitu, autonomii, vůli pacienta, multidisciplinaritu a komplexnost péče. Srov. Standardy mobilní specializované paliativní péče $v$ ČR, Praha: Česká společnost paliativní medicíny ČLS JEP a Fórum mobilních hospiců, 2019, s. 8. Dále srov. Fórum mobilních hospiců, Etický kodex: Fórum mobilních hospicu, čl. IV., srov. RADBRUCH, Standardy..., s. 21-23. Srov. Ondřej SLÁMA a kol., Standardy paliativní péče 2013, Praha: Česká společnost paliativní medicíny České lékařské společnosti Jana Evangelisty Purkyně, 2013, s. 5. Srov. Asociace poskytovatelů hospicové paliativní péče, Standardy hospicové paliativní péče, Praha: APHPP, 2016, s. 3. Oběma hodnotám se podrobně věnuje také Doporučení Rady Evropy. Srov. Doporučení Rady Evropy č. 1418/1999 „O ochraně lidských práv a důstojnosti nevyléčitelně nemocných a umírajícich". 
v pomáhajících profesích: (1) získat uznání a lásku, (2) mít moc nad druhými lidmi a (3) mít „podíl na životě““ ${ }^{33}$ Patologický altruista svou pomocí nevědomě kompenzuje vlastní neschopnost prožívat a vyjadřovat své emoce, naplňovat své potřeby a cíle. Dochází k emoční závislosti bezmocného pomocníka na umírajícím i jeho rodině / pečující osobě. Závislost pomocníka, zahrnující skrytou potřebu zpracování vlastních prožitků, ${ }^{34}$ ho vede ke snaze vyvolávat podobné emocionální prožitky u svých klientů s nadějí, že tyto emoce dokážou akceptovat a zpracovat. Tím je popřena profesionalita i důstojnost/úcta k člověku ve smyslu Kantova kategorického imperativu, podle kterého člověk nikdy nemůže být pouze prostředkem, nýbrž sám je účelem. Bezmocný pomocník tak paradoxně ztrácí ze zřetele předmět pomáhajících profesí, jímž je sám člověk se svou zranitelností, problémem.

Závislost bezmocného pomocníka je v rozporu s pozicí umírajícího/nemocného, která je spjata s tendencí k asymetričnosti vztahu. Tj. především ve zdravotnictví se stále ještě setkáme $s$ tzv. paternalistickým modelem vztahu mezi zdravotníkem a nemocným. Bezmocný pomocník této asymetrické situace nevědomě využívá tím, že svou závislost deleguje na osoby, o které pečuje. Bezmocní pracovníci usilují často o nadbytečnou kontrolu nad klienty, která může zasahovat do soukromí umírajícího a jeho rodiny, omezovat jeho osobní vůli. V praxi pak může docházet k zacházení s dospělými jako $\mathrm{s}$ dětmi, ${ }^{35}$ a tedy $\mathrm{k}$ zásadnímu porušování lidské důstojnosti a principu „volenti aegroti suprema lex“ a k porušování postupů „lege artis“. Podle Slámy postup „lege artis“ v sobě zahrnuje společně utvářená rozhodnutí na základě plné informovanosti umírajícího, kdy je utvořen spolupracující vztah pracovníka a umírajícího. ${ }^{36}$

Ze závislosti také vyplývá, že se bezmocný pomocník může cítit ohrožen, pokud by do vztahu mezi ním a klientem / pečující osobou vstupovaly další osoby. Vzhledem k upevnění pozice bezmocného pracovníka $\mathrm{v}$ rodině může docházet $\mathrm{k}$ přebírání rolí dalších členů multidisciplinárního týmu či přímo ke slovním útokům proti jiným členům týmu (viz příklad č. 3).

\section{Syndrom pomocníka $\mathrm{v}$ péči o pozůstalé}

Příklad č. 2: Pro paní Moniku je práce s pozůstalými jedinou životní náplní. Zásadním zlomem $v$ jejím životě byla smrt manžela, kterého mohla doprovázet, když umíral v li̛žkovém hospici. Velice často o tom vypráví, dnes již jako o nejkrásnějším dni v jejím životě, který ji změnil. Tato událost ji motivovala $k$ péči o truchlící, které dnes soukromě doprovází. Paní Monika nemá dèti a nový vztah odmítá. Vnímá, že její životní poslání je právě v doprovázení truchlících, kteří ji potřebují. Z jejího vyprávění je zřejmé, jak je pro ni velice těžké se od svého zaměrení oprostit. O ničem jiném nehovoří. Vnímá, že každý člověk, kterého potkává, může být tím, kdo potřebuje její pomoc.

Paní Monika působí velice přátelsky, vstřícně, energicky a mateřsky. Roli poradce pro pozůstalé vykonávala již v několika organizacích. Její metody práce byly dalš́mi členy multidisciplinárního týmu nepochopeny a neocenèny. Ona se domnívá, že svou roli vykonávala kvalifikovanè.

Z pohledu týmu vícekrát upřednostnila sebe jako jedinou kompetentní osobu, narušovala intimní chvíle, kdy se rodina chtěla s umírajícím rozloučit o samotě. Někdy je zcela „zastoupila“. Nevědomě lpěla na každém emotivním projevu pozůstalých, které přsvědčovala o potřebě jejího kontinuálního

33 Srov. DOLEŽEL, Osobnostní..., s. 32-47.

34 „Lidé se někdy stávají pomocníky proto, že je pro ně obtížné nechat si pomoci. Z tohoto důvodu delegují závislost na své klienty.“ SCHMIDBAUER, Syndrom..., s. 8.

35 Srov. KOPŘIVA, Lidský..., s. 18.

36 Srov. Ondřej SLÁMA - Lukáš PRUDIL, Právní aspekty paliativní péče, in: Paliativní medicína pro praxi, ed. Ondřej SLÁMA a kol., Praha: Galén, 2007, s. 322. 
doprovázení. Pomoc se snažila i těm, kteři o to neméli zájem, kteři svou situaci zvládali sami či za podpory blizkých. Při práci s truchlícími odmítala jejich progresi a nedokázala žádného z nich „opustit“. Snažila se o udržování kontaktu a vytvoření pevných vztahů přerůstajících roli poradce $v$ přátelství. Nebyla schopna reflektovat své jednání v kontextu cílu doprovázení pozůstalých.

Standardem specializované hospicové péče je mj. péče o pozůstalé. ${ }^{37} \mathrm{Z}$ mnohých kazuistik ${ }^{38}$ je zřejmé, že poradenství pro pozůstalé je velice specifickou oblastí, protože existenciálně zasahuje oba subjekty vztahu, které konfrontuje s vlastní smrtelností, tématem osobní bezmoci, vlastními prožitky smrti blízkých. Špaténková možná proto uvádí, že poradenství pro pozůstalé „... vyžaduje nejen specializované znalosti a dovednosti, ale také jiný př́stup ve vztahu k pozůstalým klientům a více než jakékoli jiné pomáhající poradenství (resp. pomáhající vztah) se odvíjí především od osobnostních kompetencí poradce. (...) Kromě toho by poradce pro pozůstalé měl být vyrovnán se svou vlastní smrtelností, měl by si být vědom svých vlastních ztrát a svých reakcí na témata a situace umírání, smrti a truchlení. " ${ }^{39} \mathrm{Z}$ výše uvedeného vyplývá, že na osobnost poradce pro pozůstalé jsou kladeny vysoké nároky v oblasti introspekce, sebereflexe a kontinuální supervize, jež ovlivňují kvalitu poradenského procesu a především rozvíjí osobnost pracovníka a jeho schopnost implementovat etické principy profese do praxe. ${ }^{40}$ Avšak pro bezmocného pracovníka je charakteristická omezená schopnost sebereflexe a odmítavý postoj k supervizi.

Laickou pomoc a podporu pozůstalým (jednorázovou i pravidelnou) poskytuje v praxi kterýkoli člen hospicového týmu, nejčastěji zdravotní sestra, sociální pracovník, ošetřovatel, lékař. Vyplývá to ze skutečnosti, že pracovníci v přímé péči přicházejí často během péče o umírajícího do interakce s jeho blízkými a jsou také prvními, kteří se s pozůstalými post finem setkávají. Setkání pozůstalého s psychologem / psychoterapeutem / poradcem pro pozůstalé či duchovním se uskutečňuje zpravidla po projevení zájmu. Vhodné je především tehdy, když pozůstalý vykazuje některé faktory komplikovaného truchlení. ${ }^{41}$

V praxi se tedy s doprovázením pozůstalých setká každý pracovník z pomáhající profese v hospicové péči, přesto tato pomoc vyžaduje mnohé znalosti, dovednosti i osobní předpoklady. Musil s Doležalovou uvádějí čtyři roviny uskutečňování této pomoci: (1) psychickou, (2) pragmatickou, (3) informační a (4) ekonomickou. ${ }^{42}$ Osobnost pomáhajícího pracovníka na základě probíhajících interakcí vstupuje do vztahu s truchlícím (viz Úvod). Zároveň skrze vztah dochází i k prohloubení spirituálních aspektů života pozůstalého. Doležel v tomto kontextu upozorňuje, že dle Mezinárodní federace sociální práce každá intervence probíhá v pěti kontextech včetně spirituálního kontextu. ${ }^{43}$ Proto uvedené čtyři roviny uskutečňování pomoci bychom měli doplnit o rovinu (5) sociální a (6) duchovní.

Výše uvedenou kazuistikou poukazujeme na některá rizika spojená s péčí bezmocného pracovníka o pozůstalé. U bezmocného pomocníka dochází k situacím, ve kterých je pracovník sice motivován potřebou pomoci, ale jedná paradoxně tak, aby ukončení kontraktu s pozůstalým co

37 Srov. RADBRUCH, Standardy..., s. 25. Pozn.: Péče o pozůstalé je jeden z indikátorů specializované hospicové péče, na rozdíl od obecné formy poskytování hospicové péče, která nenabízí kontinuální péči truchlícím specializovanými pracovníky, jež jsou součástí multidisciplinárního týmu.

38 Srov. ŠPATÉNKOVÁ, Poradenství..., s. 19.

39 ŠPATÉNKOVÁ, Poradenství..., s. 19-20, 25.

40 Americká Rada pro vzdělávání v sociální práci definuje jako první tři požadavky způsobilosti k výkonu profese (1) dovednost kritického myšlení, (2) schopnost implementovat do praxe etické principy a (3) profesionalizovat svou osobnost. Srov. Oldřich MATOUŠEK, Úvod: Cíle a úrovně sociální práce, in: Metody a řízení sociální práce, ed. Oldřich MATOUŠEK, Praha: Portál, 2013, s. 15.

41 Srov. ŠPATÉNKOVÁ, Poradenství..., s. 22.

42 Zdeňka DOHNALOVÁ - Libor MUSIL, Př́ínos sdružení Dlouhá cesta pro matky a rodiny vyrovnávající se se ztrátou dítěte, Sociální práce / Sociálna práca 2/2008, s. 108.

43 DOLEŽEL, Osobnostní..., s. 39. 
nejvíce oddálil nebo aby se role ve vztahu obou subjektů změnily na přátelství. Př́ičinou takovýchto postupů je opět pracovníkova potřeba závislosti (viz bod 1). ${ }^{44}$ Proto řeší stále vznikající situace, aniž by podporoval pozůstalého v co nejvyšší míře využít vlastní schopnosti a možnosti vyplývající z jeho primárního společenského prostředí. Tento postup bezmocného pracovníka tedy nekoresponduje s cílem poradenství pozůstalým, jímž je především podpora schopnosti utvářet vlastní život bez zemřelého, budovat nové vztahy. ${ }^{45}$ Četnost setkání i jejich forma ${ }^{46}$ by se měly odvíjet od reálné potřeby pozůstalých.

U bezmocného pracovníka se opětovně objevují tendence $\mathrm{k}$ utváření výlučné kompetentnosti pomoci truchlícím. Pracovník nereflektující dostatečně symptomy komplikovaného truchlení není motivován ke včasné delegaci pozůstalého do péče jiného kompetentního odborníka. Nedodržování zásady subsidiarity, zahrnující zde nejen multidisciplinární tým, ale i externí odborníky, může mít existenciální dopady. Obzvláště u pozůstalých vykazujících rizikové symptomy komplikovaného truchlení tak může toto „nejednání“ vést k rozvoji duševních poruch, závislostí, různých forem agrese až k riziku sebevražd.

\section{Bezmocný pomocník jako člen multidisciplinárního týmu}

Příklad č. 3: Paní Ludmila je zdravotní sestra s dvacetiletou praxí. Vhospicové péči pracuje poslední dva roky, predtím dlouhodobě pracovala $v$ domově pro seniory. Motivací ke změně pracoviště bylo její vlastní doprovázení umírajících členů rodiny, především maminky a tchána. Skrze tuto zkušenost paní Ludmila vnímá smysl práce v hospicové péči. Přeje si, aby co nejvíce lidí mělo možnost zažít takový konec života, který se jí podařilo dopřát svým blízkým. Dalším motivujícím faktorem pro výběr práce byla u paní Ludmily víra v Boha. Hospic dle jejích slov nabízí větši možnost uskutečňování praktické lásky $k$ bližnímu, tedy $k$ umírajícím, kterým může ještě před smrtí nabídnout a zprostředkovat Boží pokoj a milosrdenství.

K umírajícím a jejich rodinám se projevuje velice obětavě. Má potřbu sama sebe vnímat jako toho, kdo nejodborněji a nejvíce pomáhá, koho mají umírající a jejich blízcí nejraději - více než jiné členy týmu. Usiluje o dokonalost, kterou vyžaduje nejen po sobě, ale i po ostatních kolem sebe včetně své rodiny. Vysoké nároky na sebe samu přenáši na druhé.

Ve vztahu ke svým spolupracovníkưm a nadřizeným má potíže. Vnitřně bojuje nejen o uznání klientư, ale i o prízeň a pochvalu svých nadřizených. Pokud dostane kladnou zpètnou vazbu od rodiny, ráda se jí chlubí. Na ostatní členy týmu však dokáže říci nadřizeným každé malé selhání. Bojuje především proti těm, kteři něco umí nebo ví lépe. Často je skrytě shazuje, tím si vytvárí obraz sebe sama jako dokonalého člověka. Naopak jakmile někdo prohlásí něco, co se jí nezamlouvá, hned má potřebu se obhajovat, odporovat mu. Projevuje se více jako „individuální hráč“. Spolupráce s ostatními členy týmu ji dělá potíže. Neakceptuje role ostatních členů multidisciplinárního týmu. Domnívá se, že mnohým rodinám dokáže v danou chvíli nejlépe pomoci ona sama. Myslí si, že ostatní členové týmu by mohli porušit dìvěru, kterou si umírající a jeho rodina utvořili k paní Ludmile. Ve skupině potřebuje mít hlavní slovo nebo alespoň prostor pro vlastní názor, avšak neakceptuje odlišné názory. Velký problém ji dělá mlčení. Nedokáže být ve společenství, kde nastalo na nějaký okamžik ticho. Vždy má nutkání mít hlavní slovo nebo se na něco dotazovat. Na každou otázku má také hned

44 Jinou př́činou, usilující o co nejvyšší počet interakcí mezi pracovníkem a klientem, může být paradoxně systém přerozdělování dotací v rámci MPSV a grantová činnost. V tomto kontextu se státní sociální politika může spolupodílet na popírání principů pomáhajících profesí a tím na popírání sebe sama.

45 Srov. ŠPATÉNKOVÁ, Poradenství..., s. 44-45.

46 Tj. individuální, párová, rodinná, skupinová. 
odpověd. Není schopna reflektovat upomínky svých nadřizených. Vždyt to v̌̌echno „myslí dobře“ a "nic pro sebe nechce“. Supervize odmítá, neuvědomuje si problém u sebe sama. Hledá př́ićiny konfliktư vždy u druhých osob.

Výše uvedené prŕklady představují bezmocného pracovníka jako „individuálního hráče“, který neakceptuje týmovou spolupráci ani subsidiaritu vzhledem ke svému pocitu výlučné kompetentnosti, upřednostňuje samostatnou práci s cílem získání osobních zásluh, uznání aj. Spolu s tím pak souvisí přebírání rolí členů multidisciplinárního týmu, nekompetentní jednání či dokonce zajištování si pozice skrze ponižování ostatních členů týmu. Podobné chování bezmocného pracovníka se pak stává zdrojem profesních konfliktů $\mathrm{v}$ týmu i ve vztahu $\mathrm{k}$ nadřízeným např. v kontextu neakceptování strategií rozvoje organizace či organizačních směrnic. Přičemž bio-psycho-socio-duchovní model péče o umírajícího a jeho blízké lze plně uskutečňovat pouze skrze fungující spolupráci v rámci multidisciplinárního týmu.

Patologický aktivista se také vyznačuje potřebou neustálé verbální komunikace, které lze dle Schmidbauera rozumět jako obraně před zvědoměním vytěsněných vlastních prožitků.

Syndrom pomocníka může být paradoxně nadto zesílen i skrze víru v Ježí̌̌e Krista, kterého křestansky motivovaný pomáhající přijímá jako př́íklad uskutečňování praktické lásky k bližnímu. Patologický aktivista ovšem při praktikování „bliženecké lásky“ nereflektuje svobodu každého člověka jako nejvyšší hodnotu a Boží dar. ${ }^{47}$

\section{Závěr}

V tomto př́spěvku jsme reflektovali postoje bezmocných pomocníků a důsledky jejich jednání v hospicové péči mající vliv na umírající, jejich blízké, pozůstalé i na multidisciplinární tým. Poukázali jsme tím na problém, kterým mủže být vědomá nebo nevědomá motivace mnohých pracovníků v pomáhajících profesích.

Téma syndromu pomocníka si v oblasti výzkumu žádá mnohem hlubší pozornosti. Ani tento článek zdaleka neobsáhl všechny jeho akcenty. Především je také nezbytné se dále zamýšlet nad možnostmi práce s patologickými aktivisty. Na rovině individuální je potřebné se naučit syndrom rozpoznat, reflektovat a „léčit“ - tedy kultivovat svou osobnost. Na rovině organizační se ukazuje význam role profesních etických kodexů a kompetencí, které tvoří průvodce a rámec etické praxe. Zabývání se syndromem pomocníka také může přinést praktický užitek především v tom, že „můžeme zlepšovat duševní hygienu lidí v pomáhajících profesích a pomáhat jim v budování stabilní motivace. “48 Tím je ovlivněna mj. stabilita týmu a vhodné pracovní podmínky pro naplňování cílů hospicové péče.

Lze syndrom pomocníka chápat jako selhání profesionality hospicové péče? Nezaměňujeme tento syndrom s každou tzv. filantropicky motivovanou prací pomáhajících profesí či spontánní angažovaností v pomáhajících organizacích? Obě mají svou nezastupitelnou roli v pomáhajících organizacích. Tato studie v závěru tedy nabízí více otázek než odpovědí.

Je třeba dodat, že Schmidbauer vnímá syndrom pomocníka jako cosi normálního, co v pomáhajících profesích prostě existuje. ${ }^{49}$ Ale bude třeba reflektovat rozdíl mezi pomocí a záchranou. Elisabeth Kübler-Rossová, spoluzakladatelka světového hospicového hnutí, jej popisuje těmito slovy: „Ale musite si uvědomit rozdíl mezi tím, když někoho zachraňujete - tedy když se snažíte $v$ životě

47 Srov. Papežská rada pro spravedlnost a mír, Kompendium sociální nauky církve, s. 97. Pozn. Svoboda je v křestanském pojetí dar od Boha, je projevem toho, že člověk byl stvořen jako obraz Boží $(\mathrm{Gn} 1,27)$.

48 SCHMIDBAUER, Syndrom..., s. 16.

49 Srov. SCHMIDBAUER, Syndrom..., s. 22. 
jiného člověka něco ze své vưle změnit, násilím opravit - a mezi tím, když jinému člověku pomáháte: jste mu $k$ dispozici ve chvíli, $k d y$ dospěl do takového stadia pokory, že vás o konkrétní pomoc sám požádá. A ona hranice mezi záchranářem a skutečným pomocníkem, správněfungujícím bližním, je

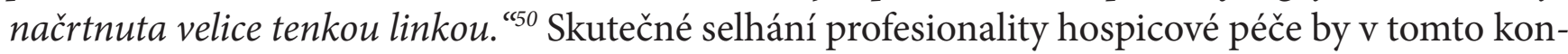
textu nastalo, pokud bychom přijali skutečnost falešných motivací pracovníků bez reflexe tohoto problému, bez hledání vhodných řešení a možností př̌konávání problémů vyplývajících z jeho důsledků.

\section{Kontakt}

\section{Mgr. Monika Vachová}

Jihočeská univerzita v Českých Budějovicích

Teologická fakulta

Katedra etiky, psychologie a charitativní práce

Kněžská 8, 37001 České Budějovice

monikaflidrova@seznam.cz 